\title{
The Clinic Online Proposal as a Lecturer Research Discussion Forum
}

\author{
Nurliana Nasution ${ }^{1}$, Mhd Arief Hasan ${ }^{2}$, Alexsander Yandra ${ }^{3}$ \\ \{nurliananst@unilak.ac.id ${ }^{1}$, m.arif@unilak.ac.id², alexsy@unilak.ac.id ${ }^{3}$ \} \\ Faculty of Computer Science, Universitas Lancang Kuning ${ }^{1,2},+6281275349990^{1}$, \\ $+06281374128355^{2}$, Faculty of Administration, Universitas Lancang Kuning ${ }^{3},+6281363063686^{3}$
}

\begin{abstract}
Currently, the development of technology is very rapidly growing and its role is very important in supporting human activities in order optimize the time better. In accordance with the mandate of the Republic of Indonesia Law Number 12 Year 2012 on Higher Education Article 1 Paragraph 9 which reads "Tri Dharma Higher Education, hereinafter referred to as Tri Dharma is the obligation of Universities to organize education, research, and society service". Based on the data of the winner of Research and Risk Research Service of 2016 fiscal year, the data obtained are stunning and not ideal. The Research title received by DIKTI in Kopertis X Region it is only 282 Proposal titles. Online forums have been widely used for many practices of organizational societies as well as virtual societies to share their knowledge and opinions. There are three main processes: (1) Registration, (2) Private Proposal Discussion Forum with Expert, (3) General Proposal Discussion Forum with Experts and other Lecturers. This system makes solution for new beginners to start research proposal, so that they will be more expert and knowledgeable about how to make a good research proposal.
\end{abstract}

Keywords : Clinic online proposal, Expert, Forum online, Lecturer

\section{Introduction}

The obligation of Universities is to organize education, research, and society service. The three basic points are things that must be done in all universities in Indonesia, especially private universities under the auspices of KOPERTIS X.

The government of Indonesia also has facilitated all roles to support the mandate of the Act. One of the information system services already provided by the government (RISTEK DIKTI) currently is SIMLITABMAS (sistem informasi penelitian dan pengabdian kepada masyarakat/ Research information system and society service). This information system has many benefits, especially in the field of Research and Services for lecturers from the process of determining the winner of a proposal to grant research and dedication for Higher Education.

KOPERTIS X supervises 84 Colleges, consisting of permanent lecturers totally 8,004 people. Based on data from the winner of the Grant Research and Service RISTEKDIKTI fiscal year 2016, the data obtained are surprising and not ideal. The title received by the Higher Education Research in the Region Kopertis X only 282 Proposal titles. Supposing 1 proposal title for 3 People lecturers means that only 10 percent of Lecturers in the Region Kopertis X who received the Higher Education Research Grants. Not to mention the DIKTI apply rules 1 People lecturer can apply maximum 2 Proposal title, if you do not have the right

ICASI 2018, April 23-24, Medan, Indonesia

Copyright $\odot 2018$ EAI

ISBN: 978-1-63190-162-1 
Index Scopus. While the data recipient at Higher Education Research Proposal for society services grant in 2016, only 50 titles KOPERTIS Proposals received in Region X.

KOPERTIS Region X is well aware of the weaknesses in terms of the low number of Grantee of Research Proposals and Community Service Funded by DIKTI for lecturers in KOPERTIS Region X. This resulted in the mandate of Law Number 12 Year 2012 on Tri Dharma College has not been well implemented. One of the main factors causing problems is the number of lecturers in the Region Kopertis $\mathrm{X}$ who do not understand well how the writing procedure of Research Proposal and DIKTI Society Service. Most of the proposals of KOPERTIS X Lecturers were rejected by DIKTI. Though the training of Proposal Research and DIKTI Services Research are often held by KOPERTIS X.

After the authors met and communicate directly with the Part KOPERTIS Region X, then appears the idea to make Clinical Proposal Online as Currently, the development of technology is growing rapidly and a very important role in supporting human activities in order to optimize the time better. One example of technology that helps human activity is information systems. The information system is a system within an organization that meets the needs of data management, support the operation, managerial and strategic activities of an organization or institution as well as providing reports for specific element. The Regional Higher Education Coordination X (in bahasa; KOPERTIS X) which is engaged in the Tri Dharma Perguruan Tinggi (three rules for higher education in Indonesia), is an extension of the Ministry of Research and Technology (in bahasa; Kemenristek DIKTI (Directorate General of Higher Education)) which requires support of information systems in improving the quality services at 84 Private Universities; called Perguruan Tinggi Swasta (PTS) is active under its auspices.

In accordance with the Law of the Republic of Indonesia Number 12 Year 2012 on Higher Education Article 1 Paragraph 9 which reads "Tri Dharma Higher Education, hereinafter referred to as Tri Dharma a Lecturer Research Discussion Forum for KOPERTIS Region X".

KOPERTIS Region $\mathrm{X}$ wants to improve this service so that the percentage of the Research and DIKTI Service for lecturers in KOPERTIS X region increases every year. KOPERTIS Region X also wants lecturers to communicate directly with the expert in the field of Research Proposal and Services through such as an application media. With the aim that the experts provided by KOPERTIS X, can do the coaching directly via the online application before the lecturers upload their proposal directly to simlitabmas.ristekdikti.go.id system.

\section{Research Method}

Technology Acceptance Model (TAM) has been used in research to explore the acceptance of new technologies or new E-Services (Davis, 1989; Davis \&Venkatesh, 1996). TAM is one of the most effective contributions of the theory of action of Ajzen and Fishbein (TRA) reasoning. Technology Acceptance Model Davis (Davis, 1989; Davis, Bagozzi, \&Warshaw, 1989) is a model of acceptance and use of the most widely used technological innovations by users. A relationship has been found between the user's beliefs about usability and technological attitudes and the intention to use the technology.

The usefulness of this technology shows more harmonious relationship with usage than other model variables. Therefore, researchers decided to use PU and PEOU in the pattern Clinic Online Proposal as a Lecturer Discussion Forum. 
Perceived usefulness (PU): Defined as the extent to which a person User believe that using a specific system will improve job performance. Perceived ease of use (PEOU): defined as the extent to which users believe that the use of a particular system would be free from intrusion attempts.

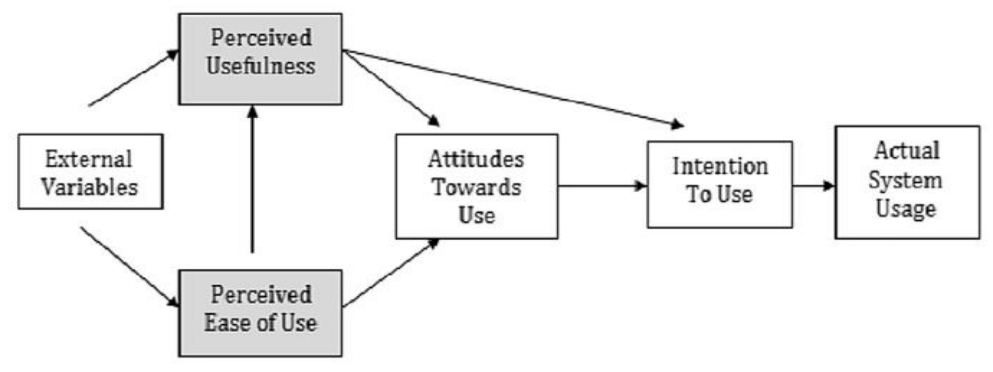

Fig. 1. Technology Acceptance Model

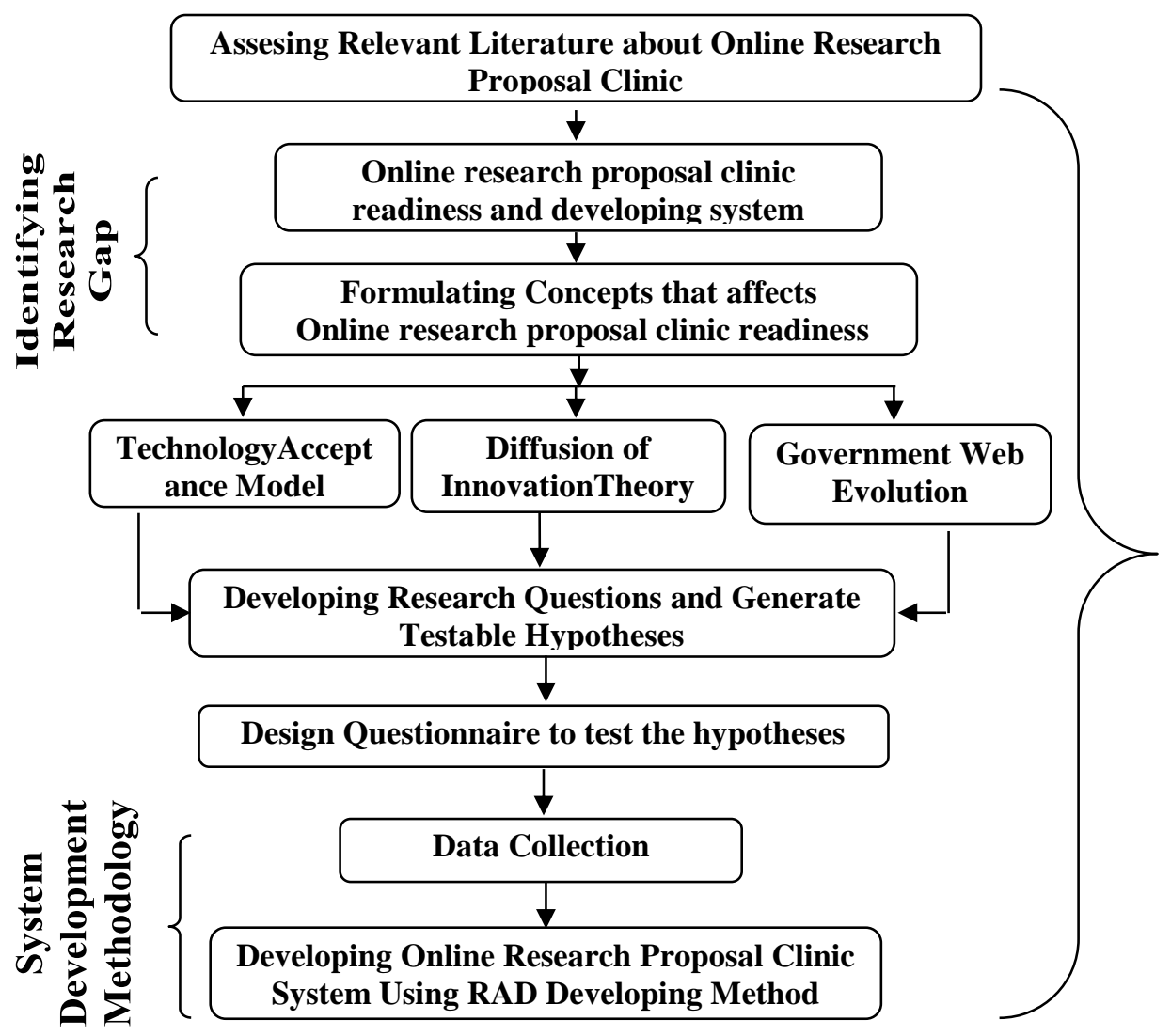

Fig. 2. Research Procedure 
Theory Diffusion of Innovations (DOI) described a model used in the study information system to explain user adoption of the new technology, (Everett Rogers, 1995). Rogers defines diffusion as the process by which an innovation communicated through certain channels over time in among social community members.Innovation is an idea or an existing object.

According to this theory, the level of diffusion is influenced by the relative advantages of innovation, complexity, compatibility, experimental capability and observation capabilities. The relative advantage is defined as the rate at which an innovation is seen as better than its predecessor. Conformity refers to the extent to which new innovations are considered new (Rogers Everett, 1995).

Government websites can be regarded as a computer and internet communication system (Sandoval-Almazan \& Gil-Garcia, 2010). There are various models that explain the development and evolution of government sites (Gil-Garcia \& Martinez-Moyano, 2007, Layne \& Lee, 2001; Sandoval-Almazan\& Gil-Garcia, 2008a, 2010). One of the most commonly used approaches is the evolutionary perspective, which creates stages and analysis of EGovernment initiatives. Appropriate characteristics and technical features are found in this stage (ie, attendance, interaction, integration). This evolutionary approach is useful for understanding the government website because it attempts to measure the level of innovation and provide guidance for development and improvement (Layne \& Lee, 2001, Moon, 2002, Sandoval-Almazan \& Gil-Garcia, 2006). This evolutionary approach includes the assumption that there is an evolution towards electronic government (Gil-Garcia \& Martinez-Moyano, 2007).

Two key issues facing the implementation of electronic government at all levels of government are collaboration and information sharing. In addition, the current changing environment, new decision-making procedures, and the complexity of the problems they face make the flow of information and the exchange of data important challenges. With the goal of better understanding this problem, scholars have developed different methodologies and models of cross-boundary information sharing and integration at the local, national, and international levels (Dawes, 2010; Gant, 2003; Gelders, Brans, Maesschalck, \& Colsoul, 2010; Klievink \& Janssen, 2010; Navarrete, Gil-Garcia, Mellouli, Pardo,\& Scholl, 2010; Papenfuß \& Schaefer, 2010; Williams et al., 2009; Zheng, Yang, Pardo, \& Jiang, 2009). In fact, as early as 1996, Dawes described the benefits and challenges of information sharing initiatives (Dawes, 1996). Information sharing can take place using a great variety of information technologies. This article argues that government portals could be a central technical component for interaction, participation, and collaboration within networks of government and non government actors. Some authors argue that each of these stages has become a government that uses electronics. Others limit the phase in which government can be considered electronic. New Studies show that evolutionary approaches are useful for understanding and evaluating E-Government, but have important limitations (Gottschalk, 2009, Sandoval-Almazan\& Gil-Garcia, 2008a, 2008b, 2009b). In addition, evaluating EGovernment, including Web Portals, using this approach can be difficult because it can have characteristics and features identified by several stages. Information, interaction, transactions, integration, and participation have been proposed as complementary components, not necessarily mutually exclusive and consecutive stages (Sandoval-Almazan \& Gil-Garcia, 2008b). This component can be used to characterize the development of Government and other E-Government websites. Initiative (Sandoval-Almazan\& Gil-Garcia, 2010) Figure 1 presents variations on this component, which position it as a function in a series of little collaboration and participation for more collaboration and participation. 


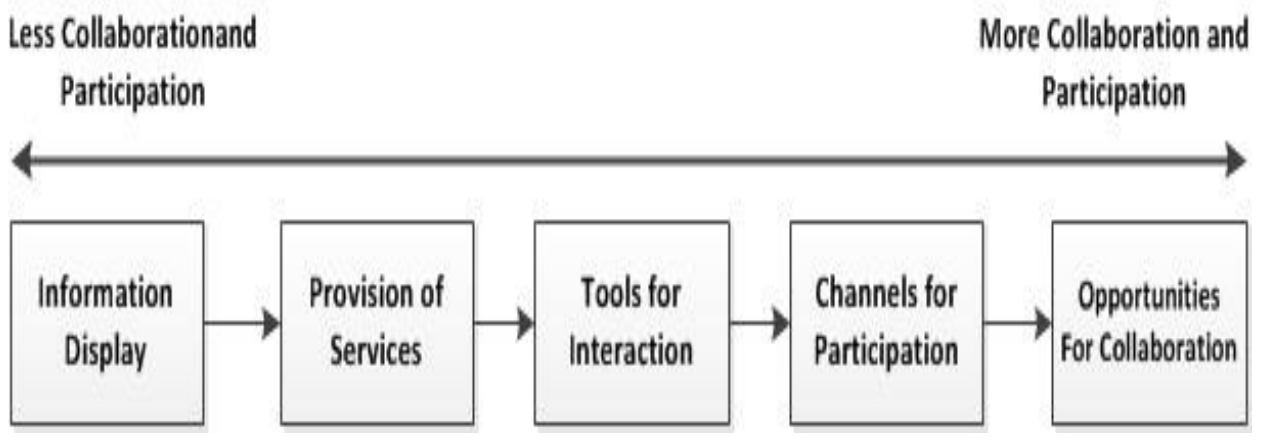

Fig. 3. Different Functions of Government Portals

\section{Results And Analysis}

The research designs reported here provide an action guide to investigate the needs of the online proposal clinical system in Kopertis X Pekanbaru. The purpose of this study is determined by that leads the formulation of research questions. To ensure that the information collected is appropriate to solve the problem, the researcher should also determine the readiness of the online proposal clinic application, sampling methodology, and schedule.

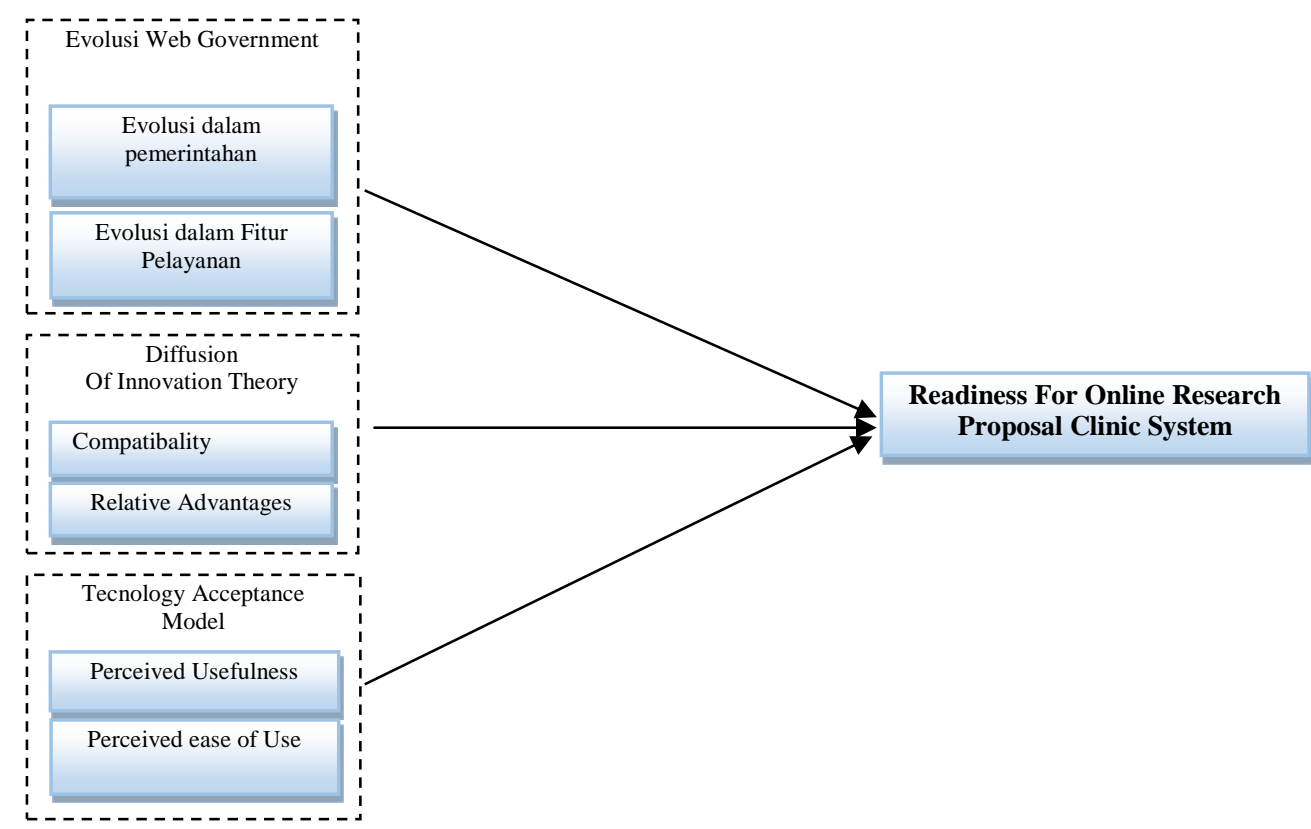

Fig. 4. Explained about the conceptual model used in the research of clinical development of online counseling services in KOPERTIS X. 


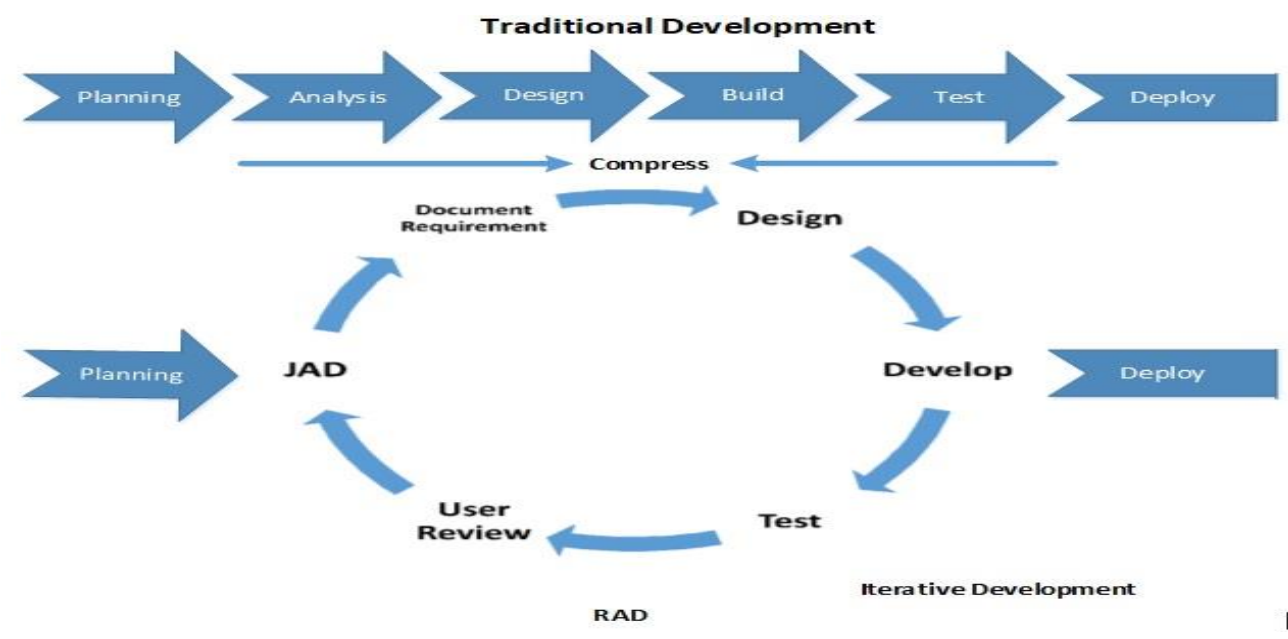

Fig. 5. Rapid Application Development (RAD) is a life-cycle strategy aimed at providinga much faster development and getting better quality results compared to theresults achieved through the traditional cycle (McLeod, 2002).

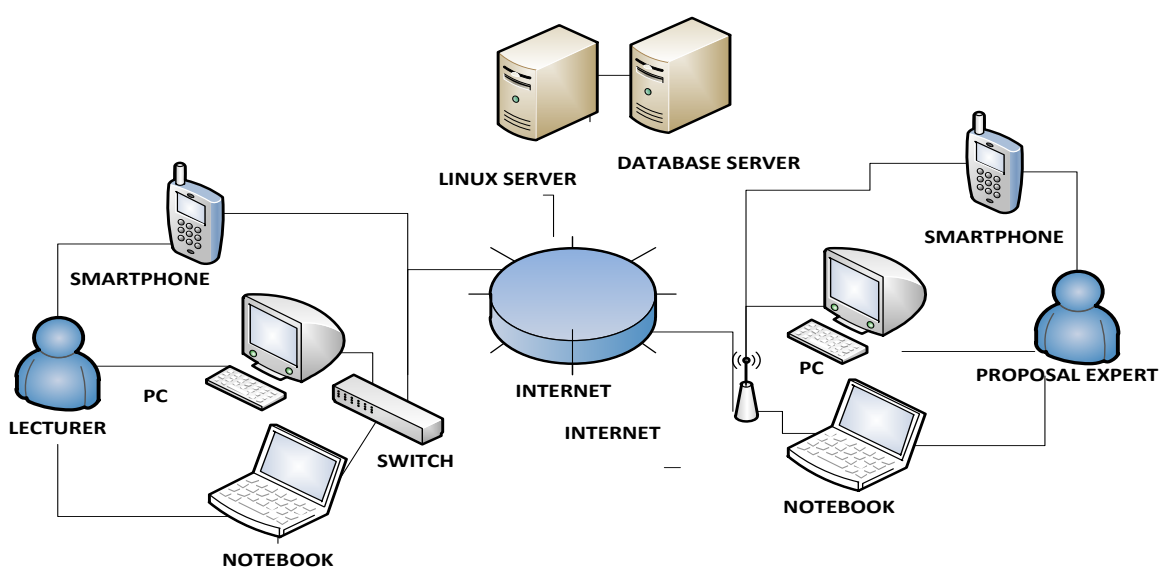

Fig. 6. Above is the framework used in the online proposal clinic forum. Users are lecturers who can interact with other lecturers for proposal clinic services via PC media, Smartphone or Notebook connected to the Intern.

\subsection{Conceptual model readiness}

The research model proposed in Figure 7.below explains how this study aims to approach the clinical readiness of online research proposals at KOPERTIS X. This research model uses three theoretical perspectives through a developed, theoretical understanding. As the base in the theoretical foundations to make the research model a better representation of reality, as it is or as it is shown in Figure 2. 


\subsection{System development}

The design is implemented at this stage. Techniques for implementation will vary depending on the artifacts to be built this project as a web-based system with detailed requirements and detailed advice previously reviewed Phase (see Figure 4).

At this stage, we must first understand the proposed behavioral system using use case modeling, which is the best way to do it, and then the process flow is determined as shown in Figure 1.The process involves:

a. Lecturer and Expert Proposal as an actor in the system.

b. There are three main processes (Registration, Discussion forum of Private Proposal with Expert, Forum of General Proposal Discussion with Expert and Other Lecturers). The system will be implemented based on Rapid Application Development (RAD) life cycle.

\subsection{RAD (Rapid Application Development)}

RAD (figure 3) is a development life cycle designed to provide faster development with higher quality results than those achieved with the traditional life cycle. It is designed to take maximum advantage of the powerful development software that has evolved recently. This section covers research questions, hypotheses, data collection and analysis to answer them. The research here proposes using the positivist method described by the deductive research approach. Hence, the starting point is the existing theory developed into a theoretical proposition that can be tested using empirical data. Once the readiness is assessed the researcher will begin to develop a prototype functional system.

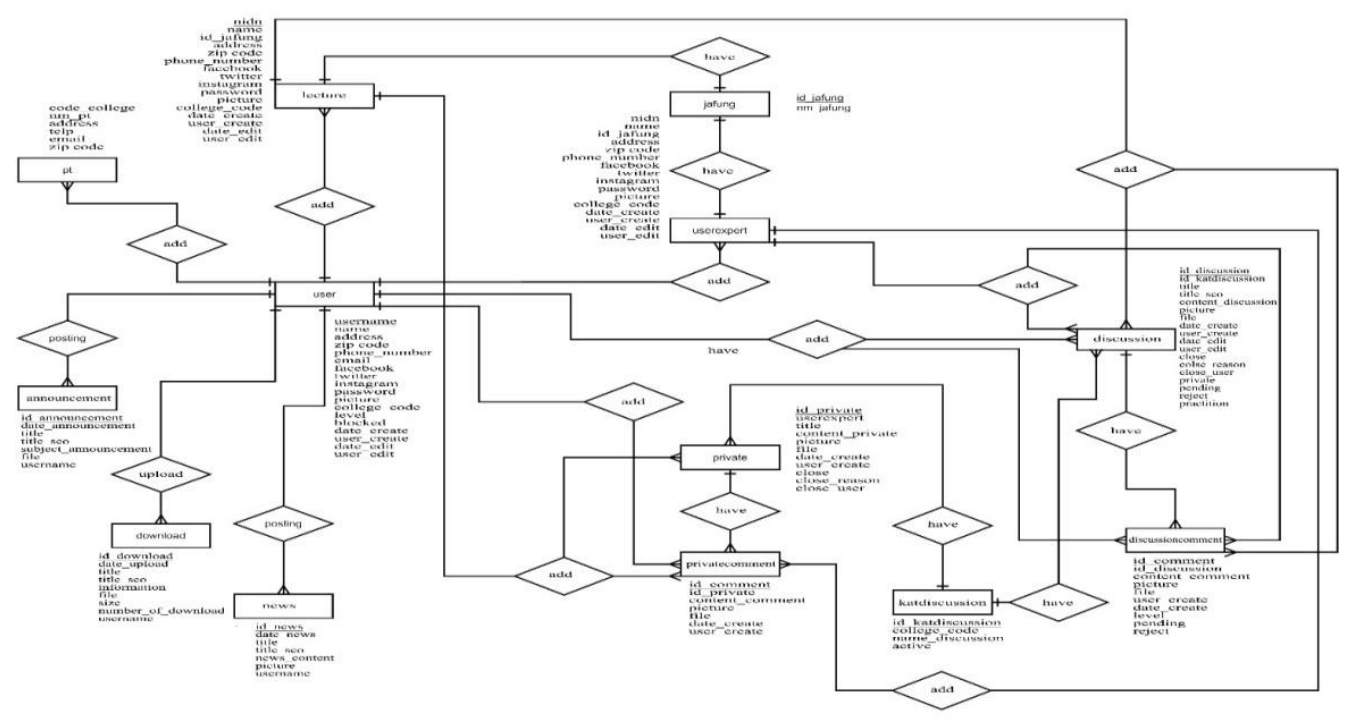

Fig. 7. This explains the relationship between entities created after the development of online clinic application forum proposal in KOPERTIS X. As illustrated in the figure. 3, lecturers and experts can login to the system in several ways, using appropriate and available communications media, polling server which is the application server. 


\subsection{Proposed framework voting system}

As illustrated in the figure. 3, lecturers and experts can login to the system in several ways, using appropriate and available communications media, polling server which is the application server. Supported entirely by Unix as an operating system, this server will connect to the database server to authenticate user data stored in the database or warehouse database (Ikonomopoulos, Lambrinoudakis, Gritzalis, Kokolakis, \&Vassiliou, 2002).

The database of proposals should be controlled by the Warehouse Management system (WMS), the Database server that includes the Database Management System (DBMS), the DBMS consists of various functions that provide large entry, storage and information retrieval and provide the ability to manage information held in the database warehouse.

\subsection{Entity Relationship Model Clinic System Proposal Online}

Entity relationship diagrams are intended to build entity relationship models, consisting of six major entities as shown in the figure. This system is more appropriately aimed at novice lecturers who are in the learning process stage in making research proposals.

The Expert Proposal is a practitioner who helps or is also called a facilitator who has more experience in research making. Especially in the research ever funded by RISTEKDIKTI. They have the role of a developed system. They communicate with each other about the proposal. Administrators are designated as users who have full rights to control the system. Full Rights in the form of additional lecturers, experts, registering college, deleted comments and so forth.

\section{Conclusion}

The research tries to find out the conceptual framework for an online proposal clinic system to apply it in KOPERTIS X; this research goes with literature, then system design to better run in KOPERTIS X environment.

Systems developed by Jordan based on the TAM model. This system makes the solution for newly started lecturers to make research proposals. So after assessed by expert knowledge they more increase how to make a good research proposal.

\section{Acknowledgements}

This research is fully funded by Indonesia government funding through research and technology ministry of fiscal year 2017. The authors thank the Ministry of Research, Technology and Higher Education (Kemenristekdikti) Indonesia. 


\section{References}

[1] Black, L. W., Wesler, H. T., Cosley, D., and DeGroot, J. M. (2011). Self-governance through group discussion in Wikipedia: Measuring deliberation in online groups. Small Group Research, 42, 595-634.

[2] Davis, F. D. (1989). Perceived usefulness, perceived ease of use, and user acceptance of information technology. MIS Quarterly,319e340.

[3] Davis, F. D., Bagozzi, R. P., \&Warshaw, P. R. (1989). User acceptance of computer technology: A comparison of two theoretical models. Management Science,35(8), 982e1003.

[4] Davis, F. D., \&Venkatesh, V. (1996). A critical assessment of potential measurement biases in the technology acceptance model: Three experiments. InternationalJournal of HumanComputer Studies, 45(1), 19e45.

[5] Dawes, S. S. (1996). Interagency information sharing: Expected benefits, manageable risks. Journal of Policy Analysis and Management, 15(2), 377-394.

[6] Dawes, S. S. (2010, 5-8 January 2010). Information policy meta-principles: Stewardship and usefulness. Paper presented at the 43rd Hawaii International Conference on System Sciences (HICSS-43), Koloa, Kauai, HI.

[7] Dawes, S. S., Cresswell, A. M., \& Pardo, T. A. (2009). From "need to know" to "need toshare": Tangled problems, information boundaries, and the building of public sector knowledge networks. Public Administration Review, 69(3), 392-402. Dawes, S. S., \&Prefontaine, L. (2003). Understanding new models of collaboration for delivering government services. Association for Computing Machinery. Communications of the ACM, $46(1), 40$.

[8] Herrington, J., Reeves, T. C., Oliver, R. \& Woo, Y. (2004). Designing authentic activities in web-based courses. Journal ofComputing in Higher Education, 16(1), 3-29.

[9] Ikonomopoulos, S., Lambrinoudakis, C., Gritzalis, D., Kokolakis, S., \&Vassiliou, K. (2002). Functional requirements for a secure electronic voting system. In Security in the information society (pp. 507e519). Springer.

[10] Mc.,Leod, R. Jr. 2002. System Development: A Project Management Approach. New York: Leigh Publishing LLC..

[11] Pan, H., Hou, E., \& Ansari, N. (2015, June). M-NOTE: A multi-part ballot based evoting system with clash attack protection. In Communications (ICC), 2015 IEEEninternational conference on (pp. 7433e7437). IEEE.

[12] Rogers Everett, M. (1995). Diffusion of innovations. New York, 12

[13] Rothwell, J. D. (2013). In mixed company: communicating in small groups and teams (8th ed.). Boston, MA: Waldsworth.

[14] Turner, J. W., Grube, J. A., and Meyers, J. (2001). Developing an optimal match within online societies: an exploration of CMC support societies and traditional support. Journal of Communication, 51, 231-251.

[15] Undang-UndangRepublik Indonesia Nomor 12 Tahun 2012 TentangPendidikan Tinggi Pasal 1 Ayat 9. 